\title{
Removal of cadmium from waste water using Saudi activated bentonite
}

\author{
S. S. Al-Shahrani \\ Department of Chemical and Material Engineering, \\ King Abdulaziz University, Jeddah, Saudi Arabia
}

\begin{abstract}
Application of Saudi activated clay (bentonite) to remove cadmium from wastewater was investigated. Natural local clay which was obtained from Khulays bentonite deposit was selected and activated using sulfuric acid to increase its adsorptive capacity. The removal characteristics of cadmium ions from wastewater were investigated under various operating variables such as contact time, initial metal concentration, clay dosage and solution $\mathrm{pH}$. Batch scale equilibrium adsorption was carried out for a wide range of initial metals concentration. The results showed that the sorption of cadmium ions on Saudi activated clay was relatively fast and the equilibrium was achieved after only $20 \mathrm{~min}$. The sorption data suggests that solution $\mathrm{pH}$ was the most important parameter in controlling cadmium sorption onto bentonite. They also showed that increasing the initial cadmium concentration decreased cadmium removal percentage due to the saturation of clay with cadmium ions. Furthermore, the adsorption of cadmium increased with increase in solution $\mathrm{pH}$. The adsorption isotherm data were well fitted with both the linearized Langmuir and Freundlich models.
\end{abstract}

Keywords: cadmium removal, Saudi bentonite, cadmium adsorption, heavy metals removal, adsorption isotherm, adsorption kinetic.

\section{Introduction}

Heavy metals wastewaters are directly or indirectly discharged into the environment excessively in many countries. Heavy metals are not biodegradable as organic contaminants and may accumulate in living organisms. Many heavy metal ions are known to be toxic or carcinogenic such as cadmium [1]. Cadmium 
is used in many applications such as electroplating, Ni-Cd batteries and paint pigments. Discharge of untreated effluents from such industries is the main source of cadmium pollution. Moreover, mining effluents and geological weathering are also considered as sources of cadmium pollution [2-4].

Cadmium is considered as a probable human carcinogen. Chronic exposure of cadmium results in kidney dysfunction whereas high levels of exposure results in death. The maximum contaminant level (MCL) is $0.005(\mathrm{mg} / \mathrm{l})$ or 5 parts per billion (ppb) [5].

Cadmium as other heavy metals can be removed from wastewater using activated carbon which is considered as the most used adsorbent, nevertheless it is relatively expensive.

Clay minerals as low-cost and easily available adsorbents have been extensively studied as adsorbents for the removal of heavy metals from aqueous solutions [6-9]. Clays mainly contain aluminosilicate minerals which have negatively charged layered that make them a good cationic adsorbents due to their relatively large surface areas. Heavy metals can be removed by adsorbing on clay surface by ion exchange reactions and by the formation of inner-sphere complexes through $\mathrm{SiO}^{-}$and $\mathrm{AlO}^{-}$groups at the clay particle edges $[10,11]$.

The adsorption capacity of natural clay can often be improved either by intercalation of organic, inorganic, or organometallic molecules in the interlamellar space, or by heat (calcination) or acid treatments according to previous studies [11-15]. These studies found that the removal characteristics of cadmium from aqueous solution by clay minerals can be affected by operating variables such as contact time, solution $\mathrm{pH}$, initial metal concentration and clay dosage. However, solution $\mathrm{pH}$ was found as the most important factor controlling the adsorption process.

The Khulays bentonite (Saudi bentonite) which is available in north of Jeddah is calcium montmorillonite equivalent to a "Texas bentonite" in the USA or Fuller's earth in the UK. The estimated reserves are ranging from 420 thousand tons to 28.9 million tons [16].

In spite of the significant resources of Saudi bentonite, few researches were conducted to use bentonite as adsorbent. Al-Shahrani [17] investigated the feasibility of producing Saudi activated bentonite from a local natural occurring bentonite from a technological and economical point view. The results showed that Saudi bentonite is suitable for acid activation. Furthermore, it was proven that Saudi activated bentonite is suitable for bleaching unbleached refined corn oil $[18,19]$. Saudi activated bentonite was used for the removal of lead and nickel from aqueous solutions. The results showed that using Saudi bentonite to remove heavy metals from aqueous solutions is promising process [20,21].

\section{Materials and methods}

\subsection{Chemicals and solutions}

All chemicals used in this work were of analytical grade reagents and used without further purifications. Cadmium was obtained from Merck. Stock solution 
of $\mathrm{Cd}(\mathrm{II})(1000 \mathrm{mg} / \mathrm{l})$ was prepared by dissolving the appropriate amounts of $\left.\mathrm{Cd}(\mathrm{NO} 3)_{2} \bullet 4 \mathrm{H}_{2} \mathrm{O}\right)$, in distilled water. The stock solutions were diluted as required to obtain standard solutions containing $20-210 \mathrm{mg} / \mathrm{L}$ of $\mathrm{Cd}(\mathrm{II})$. The $\mathrm{pH}$ of each experimental solution was adjusted to the required $\mathrm{pH}$ value using $1 \mathrm{~N} \mathrm{HCl}$ and $1 \mathrm{~N} \mathrm{NaOH}$.

\subsection{Preparation of adsorbent}

Saudi natural bentonite which was used in this study comes from Khulays bentonite deposit; $95 \mathrm{~km}$ north of Jeddah. It was not active in its natural state where some treatment was required in order to modify its adsorptive capacity. Natural Saudi bentonite samples were received as ungrounded rocks where grinding and sieving processes was conducted before acid activation. The apparatus and chemical treatment method with $\mathrm{H}_{2} \mathrm{SO}_{4}$ which was employed in this study are similar to what have been described previously [17-19]. Acid activation was done using the optimum operating variables such as $15 \%$ by weight acid concentration, the temperature of boiling, 90 minutes reaction time, grain size of -200 mesh $(74 \mu \mathrm{m})$ and water to clay ratio of $5: 1$. The chemical composition of Saudi activated bentonite revealed that $\mathrm{SiO}_{2}$ is its major $(66.2 \%)$ constituent and $\mathrm{CaO}$ is also present $(11.24 \%)$ in the adsorbent in significant amount (Table 1). Oxides of other metals are present in small amounts. The surface area of Saudi natural clay was improved from 60 to be $299 \mathrm{~m}^{2} / \mathrm{g}$ after activation process.

Table 1: Chemical composition of Saudi activated bentonite.

\begin{tabular}{cc}
\hline Compound & Chemical composition (\%) \\
\hline $\mathrm{SiO}_{2}$ & 66.2 \\
$\mathrm{Al}_{2} \mathrm{O}_{3}$ & 11.71 \\
$\mathrm{Fe}_{2} \mathrm{O}_{2}$ & 3.0 \\
$\mathrm{TiO}_{2}$ & 1.5 \\
$\mathrm{MgO}$ & 0.73 \\
$\mathrm{CaO}$ & $<0.05$ \\
$\mathrm{~K}_{2} \mathrm{O}$ & 0.48 \\
$\mathrm{Na}_{2} \mathrm{O}$ & 0.12 \\
$\mathrm{MnO}$ & 0.05 \\
$\mathrm{SO}_{3}$ & $<0.05$ \\
$\mathrm{P}_{2} \mathrm{O}_{5}$ & $<0.05$ \\
L.O.I. $\left(1000^{\circ} \mathrm{C}\right)$ & 15.3 \\
\hline
\end{tabular}

\subsection{Adsorption process}

Adsorption experiments were carried out in using batch technique. A certain amount of bentonite and $50 \mathrm{ml}$ of cadmium solution at desired initial concentration were added to $100 \mathrm{ml}$ stoppered conical flasks. The flasks were shaken in a horizontal shaker with water bath at $200 \mathrm{rpm}$. Stock solution of 
$\mathrm{Cd}(\mathrm{II})(1000 \mathrm{mg} / \mathrm{l})$ was prepared by dissolving the appropriate amounts of $\left.\mathrm{Cd}(\mathrm{NO} 3)_{2} \bullet 4 \mathrm{H}_{2} \mathrm{O}\right)$, in distilled water. The stock solutions were diluted as required to obtain standard solutions containing $20-210 \mathrm{mg} / \mathrm{l}$ of $\mathrm{Cd}(\mathrm{II})$. $\mathrm{pH}$ adjustments were carried out using $1 \mathrm{~N} \mathrm{HCl}$ and $1 \mathrm{~N} \mathrm{NaOH}$. $200 \mathrm{rpm}$ shaking rate and $25 \pm 2{ }^{\circ} \mathrm{C}$ temperature was applied in the shaker. Samples with clay content in the range of $0.125-2.0 \mathrm{~g}$ were taken from the shaker at regular contact time intervals. The sorbent and solution were separated by filtration after each run. The filtrate was analyzed for cadmium concentration by Atomic Absorption Spectrophotometer. The effects of several factors such as solution $\mathrm{pH}$, concentration of solution, clay dosage and contact time on cadmium removal efficiency were examined. The obtained data were employed to calculate the equilibrium metal uptake capacity according to the following equation:

$$
q_{e}=\frac{V\left(C_{O}-C_{e}\right)}{m}
$$

where $q_{\mathrm{e}}(\mathrm{mg} / \mathrm{g})$ is the equilibrium amount of cadmium adsorbed, $C_{\mathrm{o}}$ and $C_{\mathrm{e}}$ are the initial and equilibrium concentrations of metal ion $(\mathrm{mg} / \mathrm{l})$ in the aqueous solution, $V$ is the volume of the solution and $m$ is the sorbent dose (g) in the mixture.

\section{Results and discussion}

\subsection{Effect of contact time}

Adsorption of cadmium by Saudi activated bentonite was investigated by varying the contact time between the adsorbate and adsorbent in the range of 1-60 min. The initial concentration of cadmium was ranging from 20 to 100 $\mathrm{ppm}$, while the clay dosage was $0.5 \mathrm{~g} / 50 \mathrm{ml}$ and the solution $\mathrm{pH}$ was left unchanged at 3.2. The result showed that the amount of cadmium adsorbed increased with increase in the initial concentration and stayed constant after equilibrium as shown in fig. 1. Moreover, the data showed that the sorption of cadmium ions on Saudi activated clay was fast and the equilibrium was reached after about $20 \mathrm{~min}$, which is faster than what was reported before [12, 14, 22]. The results showed that shaking the mixture of different initial concentration for 20 minutes was sufficient to reach equilibrium. After that, contact time has no effect on metal removal percentage. They are also showed that increasing the initial cadmium concentration decreased cadmium removal percentage due to the saturation of clay with cadmium ions. For the rest of experiments, contact time was fixed at $20 \mathrm{~min}$ to ensure that adsorption equilibrium was achieved. This finding is in agreement with the results of Ulmanu et al. [23], who investigated heavy metals removal from aqueous solution using peat. 


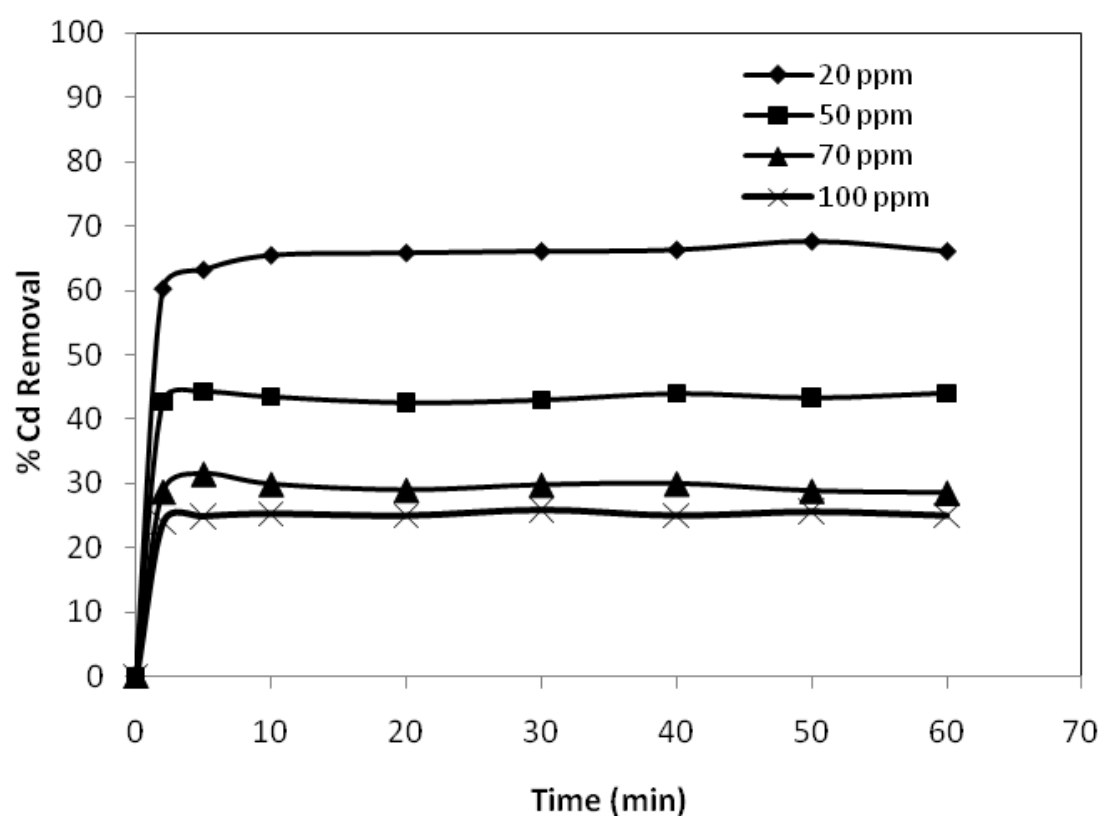

Figure 1: Effect of contact time on the removal of cadmium by Saudi activated bentonite. clay dosage: $0.5 \mathrm{~g} / 50 \mathrm{ml}, \mathrm{pH}=3.2$.

\subsection{Effect of solution $\mathrm{pH}$}

The effect of solution $\mathrm{pH}$ on the removal of cadmium ions by Saudi activated bentonite was investigated. The removal experiments were studied in the $\mathrm{pH}$ range 1-10 with a constant clay amount of $0.5 \mathrm{~g} / 50 \mathrm{ml}$ of cadmium solution, a shaking time of $20 \mathrm{~min}$ and cadmium concentration of $50 \mathrm{ppm}$. The results presented in fig. 2 reveal that the adsorption of cadmium increases from 0 to about $100 \%$ with an increase in solution $\mathrm{pH}$ from 1 to 8 . This may be explained by Saudi activated bentonite containing a large number of active sites. Therefore, it may become positively charged at low $\mathrm{pH}$, which increases the competition between $\mathrm{H}^{+}$ions and cadmium ions for the adsorption sites. Nevertheless, as solution $\mathrm{pH}$ increases, the competition decreases as bentonite surface active sites become more negatively charged, which enhances the adsorption of cadmium ions through electrostatic force of attraction [24, 25]. Beyond $\mathrm{pH} 8.0$, adsorption of cadmium does not change considerably where removal percentage is stayed around $100 \%$. It is known that cadmium hydroxide precipitate occurs when solution $\mathrm{pH}$ increases above 8 [26]. Thus, cadmium removal process at $\mathrm{pH}$ more than 8 may be caused by precipitation as well as adsorption. 


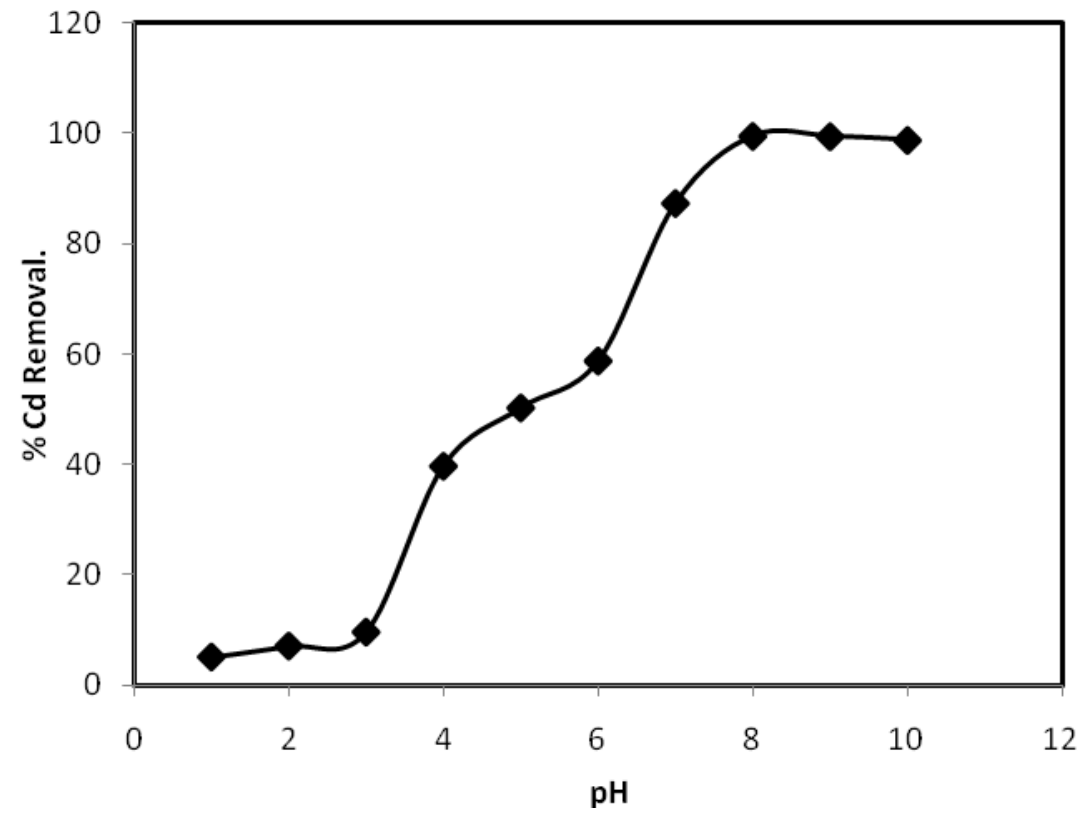

Figure 2: Effect of solution $\mathrm{pH}$ on the removal of cadmium by Saudi activated bentonite. Initial cadmium concentrations $50 \mathrm{mg} / \mathrm{l}$, clay dosage: $0.5 \mathrm{~g} / 50 \mathrm{ml}$, contact time: $20 \mathrm{~min}$.

\subsection{Effect of clay dosage}

The effect of the amount of Saudi activated bentonite on the removal of cadmium was investigated under the conditions of clay dosage $0.125-2.0 \mathrm{~g} /$ $50 \mathrm{ml}$, initial metal concentration $(50 \mathrm{ppm})$, contact time $20 \mathrm{~min}, \mathrm{pH}=7$ and temperature $\left(25 \pm 2^{\circ} \mathrm{C}\right)$. The result is shown in fig. 3 showed that the removal of cadmium increased gradually from $54 \%$ at $0.125 \mathrm{~g} / 50 \mathrm{ml}$ up to $95 \%$ at $0.75 \mathrm{~g} /$ $50 \mathrm{ml}$. Afterword, cadmium removal was stayed constant at $95 \%$ when clay dosage increased to $2.0 / 50 \mathrm{ppm}$. However, this result was expected since as the dose of the adsorbent increases, the number of adsorbent sites increases as a result of increase in adsorbent surface area. These amounts attach more ions to their surfaces [27]. Similar results were reported where many types of materials were used as adsorbents [24, 25]. 


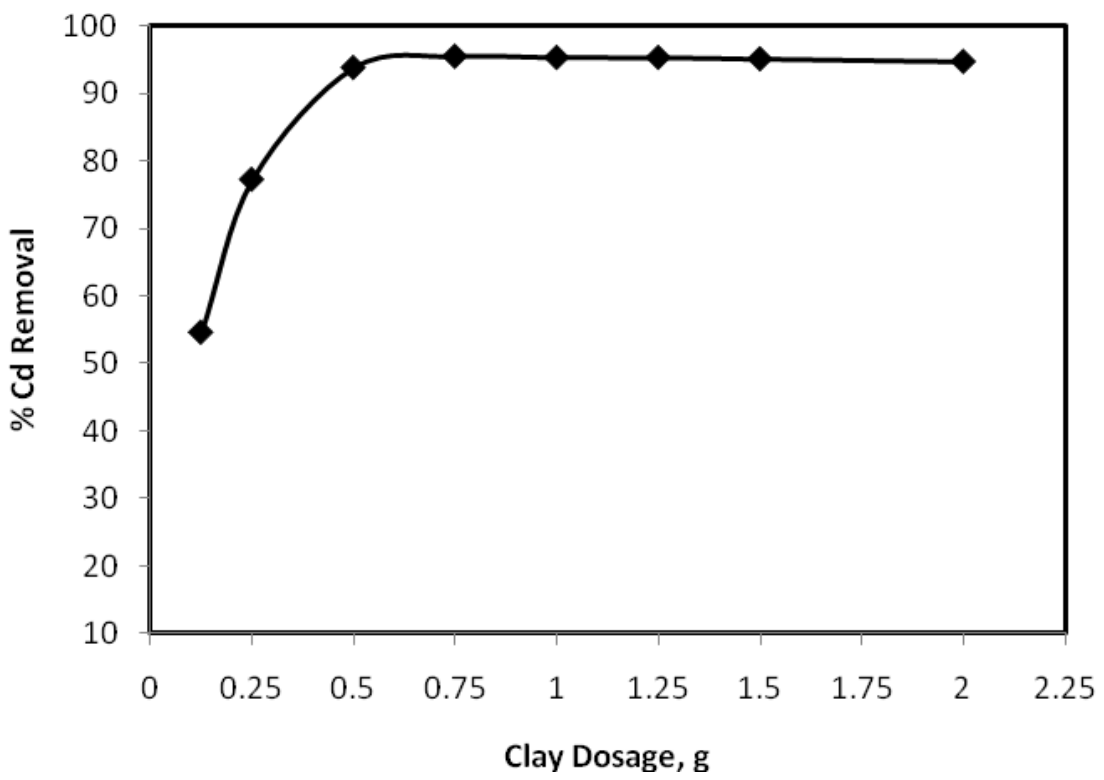

Figure 3: Effect of clay dosage on the removal of cadmium by Saudi activated bentonite. Initial cadmium concentrations $50 \mathrm{mg} / \mathrm{L}$, $\mathrm{pH}=7$, contact time: 20 minutes.

\subsection{Adsorption isotherm}

Two different adsorption isotherm models, the Langmuir [28] and Freundlich [29] equations were used to fit the experimental data obtained from this work. These models were tested to determine the maximal capacity of $\mathrm{Cd}(\mathrm{II})$ removal using Saudi activated bentonite. The quality of the isotherm fit to the experimental data is typically evaluated based on the magnitude of the correlation coefficient for the regression; i.e. the isotherm giving an $\mathrm{R}^{2}$ value closest to unity is considered to give the best fit. The adsorption isotherms for $\mathrm{Cd}$ (II) removal were studied using different initial metal concentrations at adsorbent mass of $0.5 \mathrm{~g}$ at room temperature $\left(25 \pm 2^{\circ} \mathrm{C}\right)$ and solution $\mathrm{pH}$ 7.0. Afterward, data obtained were fitted to the Langmuir and Freundlich isotherms.

The Langmuir isotherm is based on the assumption that it predicts monolayer coverage of the adsorbate on the outer surface of the adsorbent [28]. This model also suggests that there is no lateral interaction between the sorbed molecules.

The Langmuir equation, in the linear form is written as:

$$
\frac{C_{e}}{q_{e}}=\frac{1}{b q_{\max }}+\frac{C_{e}}{q_{\max }}
$$

where $\mathrm{C}_{\mathrm{e}}$ is the equilibrium concentration of metal ions $(\mathrm{mg} / \mathrm{l}), \mathrm{q}_{\mathrm{e}}$ is the amount of metal ions adsorbed per unit weight of adsorbent ( $\mathrm{mg} / \mathrm{g}$ bentonite), $\mathrm{q}_{\max }$ is the 
maximum adsorption capacity $(\mathrm{mg} / \mathrm{g})$, and $\mathrm{b}$ is the adsorption equilibrium constant $(1 / \mathrm{mg})$. The data obtained from linear Langmuir isotherm plot for Cd(II), onto Saudi activated bentonite is presented in Table 2 and plotted in fig. 4. The maximum adsorption $\left(\mathrm{q}_{\max }\right)$ of $\mathrm{Cd}(\mathrm{II})$ on Saudi activated bentonite equals to $14.9 \mathrm{mg} / \mathrm{g}$.

Table 2: $\quad$ The Langmuir and Freundlich equation parameters predicted from adsorption isotherm data of $\mathrm{Cd}(\mathrm{II})$ ions onto Saudi activated bentonite at $\mathrm{pH}=7,25^{\circ} \mathrm{C}$ and initial $\mathrm{Cd}(\mathrm{II})$ concentration of $50 \mathrm{ppm}$.

\begin{tabular}{|c|c|c|c|}
\hline \multirow{2}{*}{ Models } & \multicolumn{3}{|c|}{ Isotherm constants } \\
\hline \multirow{2}{*}{ Langmuir } & $\mathrm{q}_{\max }(\mathrm{mg} / \mathrm{g})$ & $\mathrm{b}(\mathrm{l} / \mathrm{mg})$ & $\mathrm{R}^{2}$ \\
\cline { 2 - 4 } & 14.9 & 0.0913 & 0.969 \\
\hline \multirow{2}{*}{ Freundlich } & $\mathrm{K}(\mathrm{mg} / \mathrm{g})$ & $\mathrm{n}$ & $\mathrm{R}^{2}$ \\
\cline { 2 - 4 } & 3.67 & 3.56 & 0.981 \\
\hline
\end{tabular}

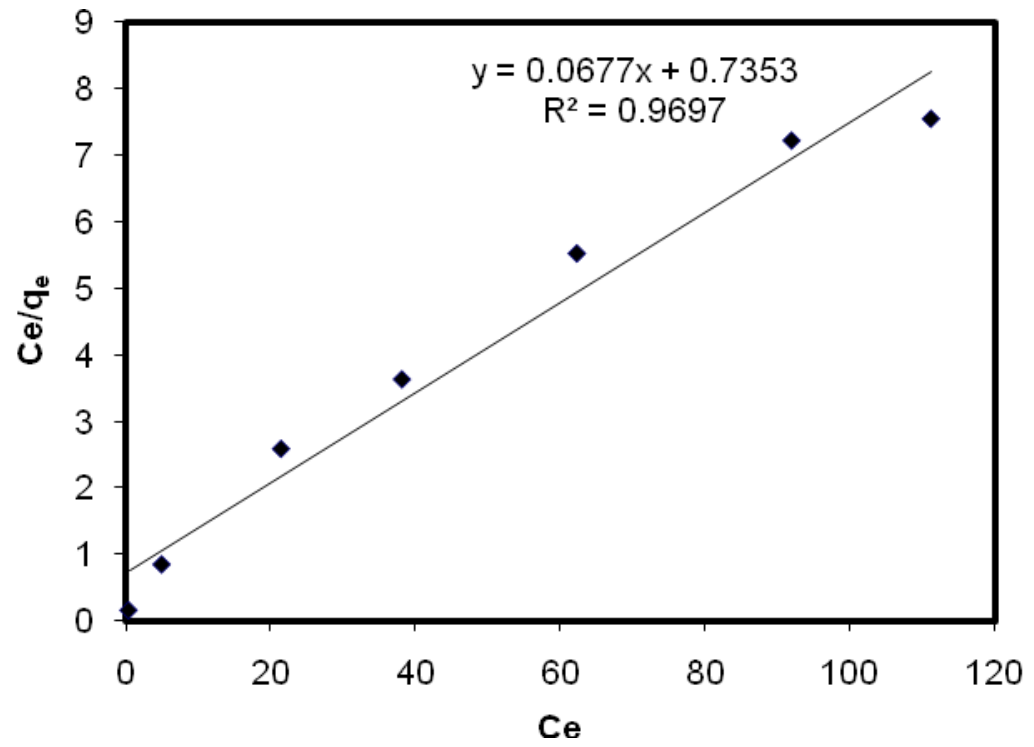

Figure 4: Langmuir plot for the adsorption of $\mathrm{Cd}(\mathrm{II})$ on Saudi activated bentonite. 
The Freundlich isotherm is based on multilayer adsorption on heterogeneous surface [29]. Linear form of for the Freundlich equation is written as:

$$
\log q_{e}=\log K+\frac{1}{n} \log C_{e}
$$

where $\mathrm{k}$ and $\mathrm{n}$ are the constant characteristics of the system.

The best estimated values of all the equation parameters are summarized in Table 2. The applicability of the Freundlich adsorption isotherm was also analyzed, using the same set of experimental data, by plotting $\log \left(\mathrm{q}_{\mathrm{e}}\right)$ versus $\log \left(\mathrm{C}_{\mathrm{e}}\right)$. The data obtained from linear Freundlich isotherm plot is presented in Table (1) and plotted in fig. 5. The value of $n$ between 1 and 10 shows good adsorption which indicating that $\mathrm{Cd}(\mathrm{II})$ is favorably adsorbed by Saudi activated bentonite.

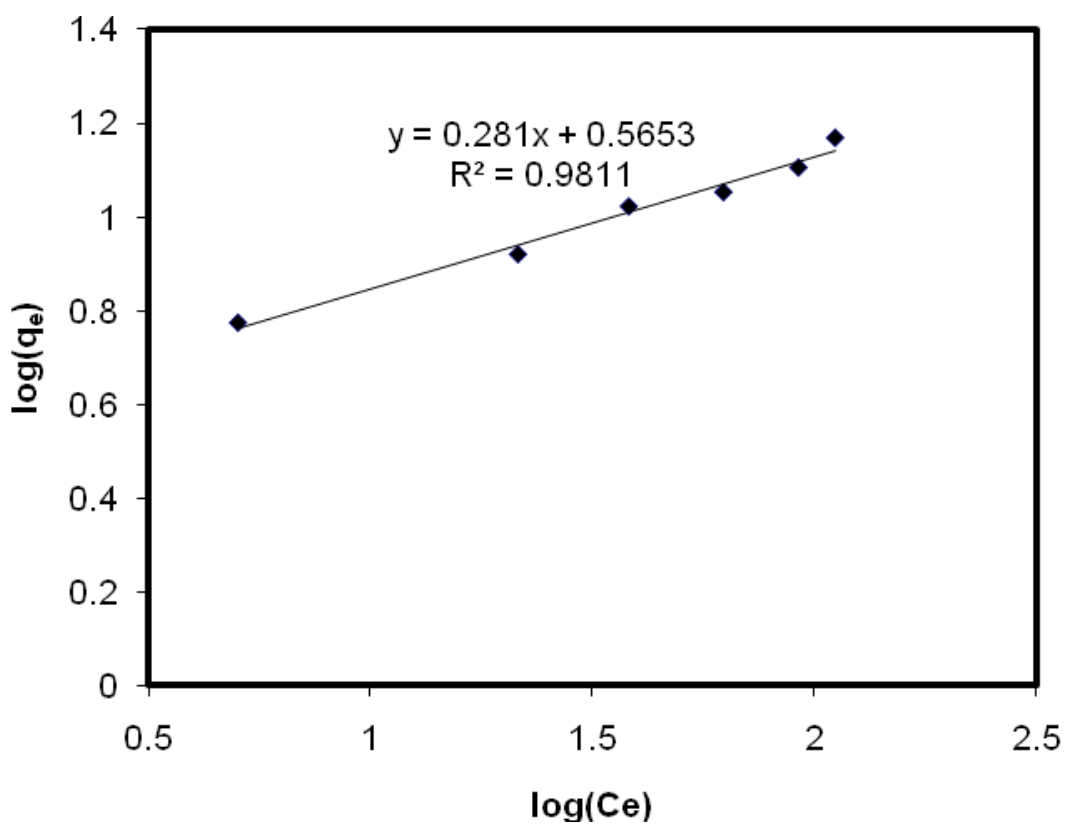

Figure 5: Freundlich plot for the adsorption of $\mathrm{Cd}(\mathrm{II})$ on Saudi activated bentonite.

The adsorption isotherm data in general are well fitted with linearized Langmuir, and Freundlich. 


\section{Conclusions}

Saudi activated bentonite was an effective adsorbent for removing Cd(II) from wastewater. Based on the experimental data, the following conclusions may be drawn:

- The sorption of cadmium ions on Saudi activated clay was fast and the equilibrium was reached after only $20 \mathrm{~min}$.

- Removal of cadmium ions by Saudi activated bentonite is effected by mixture $\mathrm{pH}$. The adsorption of metals increase with an increase in solution $\mathrm{pH}$. Increasing $\mathrm{pH}$ more than 7 may cause precipitation rather than adsorption.

- The removal of cadmium increases as the dose of Saudi activated bentonite increases. This is due to increase in the number of adsorbent sites.

- The results of this investigation show that Saudi activated bentonite has a suitable adsorption capacity for the removal of $\mathrm{Cd}$ (II) from aqueous solutions.

- The experimental results were fitted well with Langmuir and Freundlich isotherm models.

- The present study concludes that the Saudi activated bentonite could be employed as low-cost adsorbents as alternatives to commercial activated carbon for the removal heavy metals from wastewater.

\section{Acknowledgements}

The author would like to thank King Abdulaziz City for Science and Technology (KACST) for their financial support to accomplish this research (Proj. No. AT29-311). The investigator would like to thank the Department of Chemical Engineering staff, King Abdulaziz University, for their continual support and invaluable suggestions during this research.

\section{References}

[1] Srivastava, N.K., Majumder, C.B., Novel biofiltration methods for the treatment of heavy metals from industrial wastewater. Journal of Hazardous Materials. 151, pp. 1-8, 2008.

[2] Forstner, U., Wittman, G.T.W., Metal Pollution in the Aquatic Environment. Springer-Verlag, Berlin, 1979.

[3] Fribarg, L., Piscator, M., Nordbarg, G.F., Cadmium in the Environment. CRC, Cleveland, 1974.

[4] Hagino, N., Yoshioka, K., A study on the cause of 'itai-itai' disease. Journal of the Japanese Orthopaedic Association, 35, pp. 812-822, 1961.

[5] United State Environmental Protection Agency (USEPA), http://water.epa.gov/drink/contaminants/index.cfm

[6] Karamanis D., Assimakopoulos P.A., Efficiency of aluminum-pillared montmorillonite on the removal of cesium and copper from aqueous solutions. Water Research 41, pp. 1897-1906, 2007. 
[7] Tahir S.S., Rauf Naseem, Removal of Fe(II) from the wastewater of a galvanized pipe manufacturing industry by adsorption onto bentonite clay. Journal of Environmental Management 73, pp. 285-292, 2004.

[8] Vengris T., Binkiene R., Sveikauskaite A., Nickel, copper and zinc removal from waste water by a modified clay sorbent. Applied Clay Science 18, pp. 183-190, 2001.

[9] Sevil Veli, Bilge Alyüz., Adsorption of copper and zinc from aqueous solutions by using natural clay. Journal of Hazardous Materials 149, 226233, 2007.

[10] McBride M.B., Environmental Chemistry of Soils. Oxford University Press, New York, 1994.

[11] Barbier F., Duc G., Petit-Ramel M. Adsorption of lead and cadmium ions from aqueous solution to the montmorillonite: water interface. Colloids and Surfaces A: Physicochem. Eng. Aspects, 166, pp. 153-159, 2000.

[12] Sharma Y.C., Kaul S.N., Weng C.H. Adsorptive separation of cadmium from aqueous solutions and wastewaters by riverbed sand. Environmental Pollution 150, pp. 251-257, 2007.

[13] Sharma Y.C., Thermodynamics of removal of cadmium by adsorption on an indigenous clay. Chemical Engineering Journal 145, 64-68, 2008.

[14] Álvarez-Ayuso E., García-Sánchez A., Removal of cadmium from aqueous solutions by palygorskite. Journal of Hazardous Materials 147, pp. 594600, 2007.

[15] Chunlei Zhu, Zhaokun Luan, Yanqiu Wang, Xingdong Shan, Removal of cadmium from aqueous solutions by adsorption on granular red mud (GRM). Separation and Purification Technology 57, pp. 161-169, 2007.

[16] Spencer, C. H.,. The Khulays Bentonite Prospect. Ministry of Petroleum and Mineral Resources, Open-File Report BROG-OF-06-10, pp. 243-252, 1993.

[17] Al-Shahrani S., The feasibility of producing active clay from a local raw material by sulfuric acid leaching. M.Sc thesis, Chemical engineering department, King Abdulaziz University, Jeddah. 1998.

[18] Al-Zahrani A.A., Al-Shahrani S.S. and Al-Tawil Y.A., Study on the Activation of Saudi Natural Bentonite, Part II: Characterization of the Produced Active Clay and Its Test as an Adsorbing Agent. J. J. King Saud Univ., vol 13, Eng s.c i. (2), pp. 193-203, 2000.

[19] Al-Zahrani A.A., Al-Shahrani S.S. and Al-Tawil Y.A., Study on the Activation of Saudi Natural Bentonite, Part I: Investigation of the Conditions that Give Best Results and Kinetics of the Sulfuric Acid Activation Process. J. Kinig Saud Univ. Vol. 13, Eng. Sci. (1), pp. 57-72, 2001.

[20] Al-Shahrani S. S., Removal of Lead from aqueous solution using Saudi activated bentonite. Wit Trans. Ecol. Envir. 135, pp. 277-288, 2010.

[21] Al-Shahrani S. S., Removal of nickel from aqueous solution using Saudi activated bentonite. Wit Trans. Ecol. Envir. 167, pp. 461-471. 2011. 
[22] Bedoui K., Bekri-Abbes I., Srasra E., Removal of cadmium (II) from aqueous solution using pure smectite and Lewatite S 100: the effect of time and metal concentration. Desalination 223, pp. 269-273, 2008.

[23] Ulmanu, M., Anger, I., Lakatos, J., Aura, G., Contribution to some heavy metals removal from aqueous solution using peat. In: Proceedings of the First International Conference on Environmental Research and Assessment. Bucharest, Romania, pp. 185-192, 2003.

[24] Unuabonah E.I., Adebowale K.O., Olu-Owolabi B.I., Yang L.Z., Kong L.X., Adsorption of $\mathrm{Pb}(\mathrm{II})$ and $\mathrm{Cd}(\mathrm{II})$ from aqueous solutions onto sodium tetraborate-modified kaolinite clay: equilibrium and thermodynamic studies. Hydrometallurgy 93, pp. 1-9, 2008.

[25] Potgieter J.H., Potgieter-Vermaak S.S., Kalibantonga P.D., Heavy metals removal from solution by palygorskite clay. Minerals Engineering 19, pp. 463-470. 2006.

[26] Manohar D.M., Noeline B.F., Anirudhan T.S., Adsorption performance of Alpillared bentonite clay for the removal of cobalt (II) from aqueous phase. Appl. Clay Sci. 31, pp. 194-206, 2006.

[27] Mall, D.I, Srivastava, V.C. and Agarwal, N.K., Removal of Orange- G and methyl violet dyes by adsorption onto bagasse fly ash- kinetic study and equilibrium isotherm analyses. Dyes and pigments. 69, pp. 210-223, 2006.

[28] Langmuir L., The adsorption of gass, mica and platinium. J Am Chem Soc, 40, 1918.

[29] Freundlich H., Colloid and capillary chemistry. Metheum, London, 1926. 